\title{
Effect of Post-weld Heat Treatment on Microstructures and Properties of Laser-Welded FV520B Steel
}

Dewei Deng ( $\square$ cailiaoqingqibing@163.com )

Dalian University of Technology

LV Jie

Dalian University of Technology

MA Yushan

Wuzhong Instrument Co., Ltd.

TIAN Xin

Sany Heavy Industry Co Ltd: Sany Group

HUANG Zhiye

Shenyang Blower Works Group Corporation

ZHANG Yong

Shenyang Blower Works Group Corporation

FAN Qinghua

Dalian University of Technology

JIAO Yongxiang

Dalian University of Technology

Original Article

Keywords: FV520B steel, laser welding, heat treatment, $\delta$-ferrite, reversed austenite

Posted Date: September 8th, 2020

DOI: https://doi.org/10.21203/rs.3.rs-70911/v1

License: () (1) This work is licensed under a Creative Commons Attribution 4.0 International License. Read Full License 


\section{Abstract}

For the laser-welded FV520B steel welds, the experiments of post-weld aging treatment have been conducted at different temperatures. The microstructural transformations under various heat-treatment conditions are investigated by optical microscopy (OM), X-ray diffraction (XRD) and scanning electron microscopy (SEM). Vickers hardness and impact toughness are also measured after the aging treatments. The results of microstructural observations show that before heat treatment the fusion zone (FZ) mainly includes low carbon martensite and $\delta$-ferrite. With the increase of aging temperature and time, in $\mathrm{FZ}$ the $\delta$-ferrite phase spheroidizes and disappears. When the aging temperature is lower than $400{ }^{\circ} \mathrm{C}$, the carbides grow with increasing aging time. After aging treatment at $550^{\circ} \mathrm{C}$ for $12 \mathrm{~h}$, a small amount of reversed austenite appears in FZ. The volume fraction of reversed austenite increases with the further increase of aging temperature and time. However, in FZ all the reversed austenite disappears after aging at $650{ }^{\circ} \mathrm{C}$ for $12 \mathrm{~h}$. This indicates that at room temperature the amount of reversed austenite is related not only to the volume fraction of the reversed austenite obtained from aging, but also to the stability of reversed austenite during cooling. The Vickers hardness and impact toughness of the welds mainly depend on the balance between the dispersion strengthening effect of the Cu-rich precipitates and the weakening effect of tempered martensite. The presence of reversed austenite can also improve the toughness of welds. In addition, as the aging temperature and aging time increase, the hardness difference between the three zones of $\mathrm{FZ}$, heat affected zone (HAZ) and base metal (BM) decreases.

\section{Introduction}

FV520B steel is a martensitic precipitation-hardening stainless steel developed by the British FV company. This steel is ideally suited for structural materials and common applications including turbine blades, piping industries, power plants and so on due to their combination of high strength, high facture toughness and good atmospheric corrosion resistance [1-3]. In general, this steel has a $\mathrm{Cr}$ content of 10-16 wt.\%, and the Ni is also added to improve toughness by the Fe-Cr-Ni ternary alloy. Many research work has been carried out on the martensitic stainless steel, including the microstructures and mechanical properties under different compositions, weldability of the same and dissimilar metals, and heat treatment processes. Ma et al. [4] investigated the effect of $\mathrm{N}$ on microstructures and mechanical properties of $16 \mathrm{Cr} 5 \mathrm{Ni} 1 \mathrm{Mo}$ martensitic stainless steel after normalizing and tempering treatment. They found that the addition of $0.1 \mathrm{wt} . \% \mathrm{~N}$ could suppress the appearance of $\delta$-ferrite in normalized martensitic stainless steel and retard the formation of reversed austenite, which leads to a decrease in toughness of steel. Saeidi et al. [5] studied the microstructures and properties of 420 martensitic stainless steel fabricated by selective laser cladding (SLM) before and after tempering. They found that the microstructure of SLM 420 before tempering was $0.5 \sim 1 \mu \mathrm{m}$ sized cells and submicron martensitic needles with austenite. The amount of austenite after tempering at $400{ }^{\circ} \mathrm{C}$ increased, which led to a high strength of SLM 420 steel with good ductility. The martensitic precipitation-hardening stainless steel was developed by adding precipitation-hardening elements such as $\mathrm{Nb}, \mathrm{Mo}, \mathrm{Cu}, \mathrm{Ti}$, etc. in the martensitic stainless steel. Wang et al. [6] investigated the evolution of Cu-rich precipitates and their effects on the mechanical properties of 17-4 precipitation-hardening stainless steel aged at $450^{\circ} \mathrm{C}$ by high-resolution transmission electron microscopy (HRTEM) and atom probe tomography (APT). The results showed that with the increase of aging time, the changes in microstructure and 
composition of the precipitated phase caused the strength and hardness of the steel to increase significantly first and then decrease slightly, while the impact toughness changed in the opposite trend. Nakashima et al. [7] studied the precipitation strengthening mechanism of the Cu particles precipitated in Fe-Cu alloys after solution and aging treatments. They found that the precipitation strengthening mechanism of Cu particles depended not only on the average interparticle spacing but also on the particle size. The Orowan mechanism can operate at the particle sizes larger than $70 \mathrm{~nm}$, while the shear mechanism dominates at the particle sizes smaller than $70 \mathrm{~nm}$.

For the martensitic precipitation-hardening stainless steel, the reversed austenite will be formed during aging at higher temperatures. The reversed austenite contains much more austenite-forming elements such as $\mathrm{Ni}$ and $\mathrm{Mn}$, which improve the stability of austenite, thereby suppressing martensite transformation at lower temperatures. Many research works on the reversed austenite in aging martensitic steel have been reported. Leem et al. [8] investigated the transformation mechanism of low-carbon martensitic stainless steel at different heating rates and the influence factors of retained reversed austenite content at room temperature. The results indicated that when the heating rate exceeded $10^{\circ} \mathrm{C} / \mathrm{s}$ the transformation of martensite into reversed austenite changed from diffusion control to diffusionless control.

Laser welding has become one of the most promising joining technologies due to its high quality, high accuracy, high speed and low post-weld deformation [9]. Its applications are increasing, but it is still rarely studied and applied in the manufacturing of large compressor impellers. For FV520B steel used in impeller, the laser welding joint has a higher strength and lower plasticity and toughness. Hence heat treatment is required after welding in order to make the joint have a better combination of strength and toughness. This study focuses on the microstructural evolution, hardness distribution and impact toughness of laser-welded FV520B steel after aging treatments under different temperatures.

\section{Experimental Details}

In this work, the hot-rolled FV520B steel sheets were used as the base metal (BM). The alloy composition of FV520B steel is listed in Table 1. The butt welding plates were cut into the size of $95 \mathrm{~mm} \times 95 \mathrm{~mm} \times 5 \mathrm{~mm}$. The welding equipment is a remote laser welding system as shown in Fig. 1. The welding experiments were conducted using the TruDisk laser produced by TRUMPF with a $6600 \mathrm{~W}$ maximum power, an $8.0 \mathrm{~mm} \times$ mrad beam quality and a $200 \mu \mathrm{m}$ fiber diameter. The ALO3 laser head is fixed on a six-axis robotic arm (KR 120 R2700).

The experimental plates were fixed on the clamp after cleaning surface contaminations with alcohol. The laser welding was performed under the optimized parameters of $4.2 \mathrm{~kW}$ power, $35 \mathrm{~mm} / \mathrm{s}$ welding speed, 1.2 $\mathrm{mm}$ beam spot, and $10 \mathrm{~L} / \mathrm{min}$ shielding gas flow. The welded specimens were heat-treated in a resistance furnace at temperatures of $300-900^{\circ} \mathrm{C}$ and holding times of $9 \mathrm{~min}-12 \mathrm{~h}$.

The as-welded and aged specimens for microstructural investigation were cut from the cross-section of joints, polished and then etched with Marble's reagent $\left(50 \mathrm{ml} \mathrm{H}_{2} \mathrm{O}+50 \mathrm{ml} \mathrm{HCl}+10 \mathrm{~g} \mathrm{CuSO}_{4}\right)$. The microstructure was observed using Nikon ECLIPSE MA100 optical microscope (OM) and Zeiss Supra 55 field emission scanning electron microscope (SEM) with energy dispersive spectroscopy (EDS). The phase 
composition was identified by a Shimadzu XRD-6000 X-ray diffractometer (XRD) with scanning step size of 0.02 and scanning speed of $2 \mathrm{deg} / \mathrm{min}$. The microhardness was examined in the middle part on transverse section of welds by a MVC-1000B Vickers hardness tester, with $300 \mathrm{~g}$ load and $15 \mathrm{~s}$ holding time. The impact test was performed on a JB-300B impact tester with maximum impact energy of $300 \mathrm{~J}$ at room temperature. The impact specimens were processed according to GB/T 2650-2008, and the notch was placed on the weld.

\section{Results And Discussion}

\subsection{Effect of post-weld heat treatment on weld microstructure}

The microstructures of BM and fusion zone (FZ) of weld are shown in Fig. 2. It can be seen that the BM mainly consists of white martensite with black carbides in Fig. 2(a), and grains are distributed in a band shape along the rolling direction as shown in Fig. 2(b). In Fig. 2(c), the prior austenite grains in FZ grow in a manner of columnar, and the martensitic laths present a parallel alignment in the grain interior. The $\delta$-ferrite is distributed at the prior austenite grain boundaries (PAGB) and present two forms, the worm-shaped ferrite parallel to the growth direction of prior austenite and the non-parallel lathy ferrite. The mean content of $\delta$ ferrite in $\mathrm{FZ}$ was evaluated by image processing software to be about 6 vol.\%. It has been reported that the 5 15 vol.\% $\delta$-ferrite content in stainless steel weld can significantly suppress the solidification cracking of welding $[1,10]$. Fig. 2 (d) shows the local morphology at high magnification of FZ. It can be seen that a small quantity of nano-sized carbide particles is distributed in the martensite matrix. The X-ray diffraction patterns for BM and FZ of weld are shown in Fig. 3. It can be found that there is a small amount of retained austenite in BM. The absence of austenite diffraction peaks in FZ confirms that the retained austenite has completely transformed into martensite after welding. The volume fraction of austenite at room temperature was calculated according to the following method by measuring the integrated intensities of (110) $a^{\prime}$ and $(111)_{Y}$ diffraction peaks [11]

$$
\begin{gathered}
V_{\alpha^{\prime}}+V_{\gamma}=1 \\
V_{\gamma}=\frac{1.4 I_{\gamma}}{I_{\alpha^{\prime}}+1.4 I_{\gamma}}
\end{gathered}
$$

Where $V_{a^{\prime}}$ and $V_{\gamma}$ are the volume fraction of $\gamma$ austenite and $a$ martensite, respectively. $I_{a^{\prime}}$ and $l_{\gamma}$ are the integrated intensities of $(110)_{a^{\prime}}$ and $(111)_{Y}$ diffraction peaks, respectively. Using the above equations, the volume fraction of retained austenite of BM is determined as 8.4 vol.\%.

Fig. 4 gives the SEM images of microstructural evolution in FZ under all the heat treated conditions. With the increase of aging time, the amount of carbides precipitated along PAGB and martensitic lath boundaries increase, and $\delta$-ferrite is still visible at aging temperatures of $300^{\circ} \mathrm{C}$ and $400^{\circ} \mathrm{C}$. At the aging temperature of $550^{\circ} \mathrm{C}$, the $\delta$-ferrite gradually spheroidizes, and eventually disappears as the aging time increases.

Simultaneously, the characteristic of columnar grains in FZ also disappears. When aging at $600{ }^{\circ} \mathrm{C}$ and 650 
${ }^{\circ} \mathrm{C}$, the processes of spheroidization and disappearance of $\delta$-ferrite accelerated. Furthermore, at the higher temperature of $900^{\circ} \mathrm{C}\left(\mathrm{A}_{\mathrm{c} 3}\right.$ temperature of FV520B steel is about $900^{\circ} \mathrm{C}$ [12]) austenitization occurs. With the increase of holding time, the martensitic laths become coarse after cooling.

Fig. 5 shows the SEM images of FZ under some particular heat-treatment parameters at the higher magnification of $15000 \times$. As can be seen in Fig. $5(\mathrm{a})$, at $400{ }^{\circ} \mathrm{C}$ for 9 min many fine granular-shaped and needle-shaped carbides appear within the size range from tens to hundreds of nanometers. According to the study of Lu et al. [13], the precipitates with the same morphology were also found in the $\mathrm{Cr} 13$ martensitic stainless steels tempered at $300^{\circ} \mathrm{C}$, and this carbide was identified as $\mathrm{M}_{3} \mathrm{C}$ type ( $\mathrm{M}$ is Fe or $\mathrm{Cr}$ ) by transmission electron microscopy (TEM). As show in Fig. 5(b), the size of carbides increases, while the tempered martensite still retains the lathy feature. During laser welding the high cooling rate of the weld causes that there is no sufficient time for the precipitation of alloy elements, thus leading to the formation of the unstable supersaturated solid solution. The alloy elements in supersaturated solid solution tend to precipitate in the form of carbides, and the size of carbides also increases with aging time. The coarsening of prior austenite grain boundaries (PAGBs) may be related to the precipitation of carbides at grain boundaries. The precipitation of carbides results in the continuous rejection of carbon atoms from the martensite which causes a decrease of the tetragonality of the martensite matrix [14], thereby forming tempered martensite. Fig. 5(c) and 5(d) show the microstructures aged at $550{ }^{\circ} \mathrm{C}$ for $2 \mathrm{~h}$ and $12 \mathrm{~h}$, respectively. In Fig. 5(c) the lathy feature of the tempered martensite can still be observed, while after aging for $12 \mathrm{~h}$ the nucleation of new phases occurs at the PAGBs and these phases grow inside the prior austenite grains along the boundaries of martensite laths. Such phases can also be seen in the weld aged at $600{ }^{\circ} \mathrm{C}$ for $1 \mathrm{~h}$ (Fig. 5(e)). It was reported that the reversion from martensite to austenite will occur when maraging steel is heated close to the $A_{c l}$ temperature $[8,15]\left(A_{c 1}\right.$ temperature of FV520B is about $\left.580^{\circ} \mathrm{C}[16]\right)$. During cooling, the austenite is expected to two types of transformation. The first is the forming of martensite, and the other is the forming of the more stable reversed austenite due to the high content of austenite stabilizing elements ( $\mathrm{Ni}, \mathrm{Mn}$, etc.). Thus, it can be speculated that the relevant phases in Figs. 5(d) and 5(e) may be the reversed austenite which formed by reversed transformation and retain their morphology at the aging temperature after cooling. Its composition may be martensite, reversed austenite, or a mixed structure of martensite and reversed austenite. After aging at $600^{\circ} \mathrm{C}$ for $12 \mathrm{~h}$, the strip-shaped and granular phases are distributed in the tempered martensite matrix. It is supposed that the phases in Fig. 5(f) are formed by the growth of the above-mentioned phases. As shown in Fig. $5(\mathrm{~g})$ and $5(\mathrm{~h})$, at aging temperature of $650^{\circ} \mathrm{C}$ the strip-shaped and granular grains are formed after only $1 \mathrm{~h}$ and obviously coarsened after $12 \mathrm{~h}$.

EDS results of the positions denoted by the arrows in Figs. 5(e) and 5(f) are shown in Table 2. In Fig. 5(e), the Cu content at the position 1 is higher than the average content of the base metal. It indicates that the segregation of $\mathrm{Cu}$ has occurred here. It has been reported that $\mathrm{Cu}$ bearing martensitic precipitation hardened stainless steel will precipitate nano-scale Cu-rich particles during aging treatment $[6,17]$. The Ni content at positions 2 and 3 is higher than the average content of the base metal. It implies that the segregation of $\mathrm{Ni}$ has occurred at these positions. The reversed austenite may be formed in Ni-rich regions after aging. However, it is difficult to use SEM to observe the morphology of reversed austenite in martensitic matrix due to its small size. 
Fig. 6 shows the XRD patterns of the FZ under different heat treatment conditions. At room temperature the volume fraction of reversed austenite can be calculated using Eq. (1) and (2), and its variation with aging time is plotted in Fig. 7. At aging temperature of $550{ }^{\circ} \mathrm{C}$ the reversed austenite diffraction peaks cannot be found at $2 \mathrm{~h}$, while after a longer aging time of $12 \mathrm{~h}$, the amount of reversed austenite reaches 7.0 vol.\%. When the aging temperature increases to $600{ }^{\circ} \mathrm{C}$, there is no reversed austenite under the holding times below $1 \mathrm{~h}$. As the aging time increases to $1 \mathrm{~h}, 2 \mathrm{~h}$ and $12 \mathrm{~h}$, the volume fraction of reversed austenite reaches 2.9 vol.\%, 9.0 vol.\% and 15.6 vol.\% respectively. When the aging temperature further rises to $650{ }^{\circ} \mathrm{C}$, the reversed austenite is formed after aging for only $9 \mathrm{~min}$. Additionally, it is noted that the amount of austenite increases first and then decreases with increasing time. In particular, after aging for $12 \mathrm{~h}$ the FZ no longer contains the austenite at room temperature. The amount of reversed austenite is related to the content and stability of the austenite formed during aging. Furthermore, the amount of austenite during aging is associated with the temperature and the holding time. The higher temperature and the longer time are desirable for the formation of austenite. The stability of austenite at the aging temperature is related not only to the content of austenite-stabilizing elements such as $\mathrm{Ni}$ and $\mathrm{Mn}$ in austenite, but also to the concentration of vacancies $[8,14,15]$. When the aging temperature is at $550^{\circ} \mathrm{C}$, the reversed transformation occurs in a diffusion manner, then it requires a long time to obtain austenite. When heated to $600{ }^{\circ} \mathrm{C}$, the formation rate of reversed austenite becomes faster, and so the amount of reversed austenite at room temperature also increases. The reason why the reversed austenite disappears at the aging condition of $650{ }^{\circ} \mathrm{C}$ and $12 \mathrm{~h}$ can be explained as follows. The limited $\mathrm{Ni}$ concentration and the increasing reversed austenite at the aging temperature give rise to a decrease of the average content of $\mathrm{Ni}$ in austenite, resulting in a decrease in the stability of austenite and an increase in the $M_{s}$ point. Therefore, all austenite is transformed into martensite during cooling [18]. Wang et al. [6] found that as aging time was prolonged, the segregation of $\mathrm{Ni}, \mathrm{Mn}, \mathrm{Si}$ and $\mathrm{Nb}$ occurred and the co-precipitates were formed accompanied with precipitation of $\mathrm{Cu}$. This is also one reason of a decrease of $\mathrm{Ni}$ content in reversed austenite.

\subsection{Effect of post-weld heat treatment on Vickers hardness and impact toughness of weld}

Fig. 8 shows the Vickers hardness of the weld in as-welded and different heat treated conditions. For the aswelded specimen, the hardness of FZ is higher than that of the heat affected zone (HAZ) but slightly lower than that of the BM. At aging temperatures of $300^{\circ} \mathrm{C}$ and $400^{\circ} \mathrm{C}$, the average hardness of $\mathrm{FZ}$ and $\mathrm{HAZ}$ increases with aging time, and the hardness difference between the three regions narrowed. In the aging temperature range of $550-650^{\circ} \mathrm{C}$, the hardness curves of welds present the maximum values at the aging time of $9 \mathrm{~min}$, and then decrease with increasing aging time.

The increase in hardness during aging is mainly related to the dispersion strengthening caused by the precipitation of Cu-rich phases in a nanoscale $[7,19,20]$. Below the temperature of $400{ }^{\circ} \mathrm{C}$, the precipitation rate of $\mathrm{Cu}$-rich phase is lower. However, when aging temperature is not lower than $550^{\circ} \mathrm{C}$, the high precipitation rate makes the number of Cu-rich precipitates increase sharply in a short time, resulting in a high level hardness. However, the Cu-rich precipitates gradually grow with increasing holding time, thus leading to a weakening of dispersion strengthening effect. Additionally, the increase of tempered martensite and the occurrence of reversed austenite with aging time will also give rise to a softening effect which can even overcome the dispersion strengthening, resulting in a lower hardness compared with the as-welded. 
At the same parameter three parallel samples were prepared for the impact toughness test. The mean values of the absorbed impact energy of the welded joints under different heat treatment processes are presented in Fig. 9. At aging temperatures of $300^{\circ} \mathrm{C}$ and $400^{\circ} \mathrm{C}$, the impact toughnesses of welds are lower, and have a similar variation trend which first increase and then decrease with holding time. At the same holding time, the absorbed impact energies of the welds under aging temperature of $400^{\circ} \mathrm{C}$ are higher than that under $300^{\circ} \mathrm{C}$. At aging temperature of $550^{\circ} \mathrm{C}$, the impact toughness first decreases and then increases with holding time, the absorbed impact energy reaches the highest value of $61 \mathrm{~J}$ at aging time $12 \mathrm{~h}$. For Fe-Cr alloys the Cr-rich ferrites will be formed at the elevated temperatures from $475^{\circ} \mathrm{C}$ to $550^{\circ} \mathrm{C}$ [1], and this results in the decrease of impact toughness after aging treatment. However, at the longer aging time of $12 \mathrm{~h}$ the impact toughness of the weld is improved due to the formation of reversed austenite [15]. At aging temperature of $600{ }^{\circ} \mathrm{C}$, the absorbed impact energy gradually increased with aging time, reaching the maximum of $75 \mathrm{~J}$ at aging time $12 \mathrm{~h}$. Under aging temperature of $650^{\circ} \mathrm{C}$, the absorbed impact energy increases first and then decreases as the aging time increases, reaching the maximum at aging time $2 \mathrm{~h}$. Combined with the XRD results, it can be found that the impact toughness improves as the content of reversed austenite increases. In addition, with the increase of aging temperature and time, the growth of non-coherent Cu-rich precipitates can also lead to a decrease in hardness and an increase in impact toughness [14].

Fig. 10 shows the impact fracture morphologies of the specimens at aging temperatures of $550{ }^{\circ} \mathrm{C}$ and 650 ${ }^{\circ} \mathrm{C}$ under different aging times. At temperature of $550^{\circ} \mathrm{C}$ and aging time below $2 \mathrm{~h}$, as shown in Fig. 10(a), 10 (c) and 10(e), the fractographs exhibit the quasi-cleavage characteristics, which correspond to the lower toughness. At aging temperature $550^{\circ} \mathrm{C}$ for $12 \mathrm{~h}$, as shown in Fig. $10(\mathrm{~g})$, the large number of dimples on the fracture surface imply an improvement in the toughness of weld. The EDS analyses of the short rod-shaped second phase (denoted by the arrow in Fig. 10(e)) shows the element content 8.83Cr-1.48Ni-29.37Mn-18.85S (wt. \%). The higher contents of $\mathrm{S}$ and $\mathrm{Mn}$ indicate that the second phase may be MnS. At aging temperature of $650^{\circ} \mathrm{C}$, the specimens under four different aging times all show the dimple-like characteristics corresponding to a good toughness. Fig. 10(b), 10(d) and 10(f) exhibit tear-type dimples, while Fig. 10(h) shows fine equiaxed dimples. At aging temperature of $650^{\circ} \mathrm{C}$ for $12 \mathrm{~h}$, the finer dimples, which is likely to be related to the formation of reversed austenite, do not produce an extra effect on the impact toughness. It differs from the significant improvement in toughness at aging temperature $550{ }^{\circ} \mathrm{C}$ for $12 \mathrm{~h}$.

Generally, the Vickers hardness presents a strong positive correlation with yield strength [20], then the value of Vickers hardness is selected to reflect the change trend of yield strength in this work. The scatter diagram of Vickers hardness vs. impact energy under all heat treatment conditions is plotted in Fig. 11, and the point number in the diagram is consistent with the heat treatment parameters in Table 3 . In order to compare the variation of properties under different heat treatment parameters with the as welded, the diagram is divided into four parts by the dotted lines across the as-welded point. As shown in Fig. 11, the scatter diagram can give a clear indication for the selection of desired properties of welds. The parameter points in the upper right corner area of the diagram correspond to the excellent combination of strength and toughness, such as the point numbers of 17 and 14 .

\section{Conclusions}


For the joint of laser-welded FV520B steel, the microstructure of FZ mainly contains low carbon martensite and small amounts of $\delta$-ferrite with worm-shaped or lath-shaped morphologies. The $\delta$-ferrite is still clearly visible at aging temperatures of $300^{\circ} \mathrm{C}$ and $400^{\circ} \mathrm{C}$, while at $550^{\circ} \mathrm{C}$ the $\delta$-ferrite gradually spheroidizes and eventually disappears with increasing aging time. The spheroidization and disappearance of $\delta$-ferrite tend to accelerate at the higher aging temperature of $600^{\circ} \mathrm{C}$ and $650^{\circ} \mathrm{C}$. At temperature of $900^{\circ} \mathrm{C}$ austenitization occurs, and the martensitic laths coarsen with the increase of holding time.

When aging temperature is not higher than $400{ }^{\circ} \mathrm{C}$, the carbides precipitate and grow with aging time. After aging at $550^{\circ} \mathrm{C}$ for $12 \mathrm{~h}$, only small amounts of reversed austenite were retained. With the increase of aging temperature and time, the volume fraction of reversed austenite increases. However, all the reversed austenite in $\mathrm{FZ}$ disappear after aging at $650^{\circ} \mathrm{C}$ for $12 \mathrm{~h}$. It indicates that the amount of reversed austenite at room temperature is related not only to its volume fraction formed during aging process, but also to its stability during cooling.

The mechanical properties of welds mainly depend on the combination of the dispersion-strengthening effect by the Cu-rich precipitates and the weakening effect by the tempered martensite. At aging temperature of $400{ }^{\circ} \mathrm{C}$, the dispersion-strengthening of the precipitates plays a dominant role. The hardness increases with aging time due to the increase of Cu-rich precipitates. At $550^{\circ} \mathrm{C}$ or higher aging temperatures, hardness increase only in a short aging time due to the accelerated precipitation of Cu-rich phase. However, with the further increase of aging time, the coarsening of Cu-rich precipitates and the formation of tempered martensite result in a decrease in weld hardness and an increase in impact toughness. In addition, the presence of reversed austenite also contributes to the improvement of weld toughness.

\section{Declarations}

\section{Availability of data and materials}

The datasets used and/or analyzed during the current study are available from the corresponding author on reasonable request.

\section{Competing interests}

The authors declare no competing financial interests.

\section{Funding}

Supported by Foundation of Collaborative Innovation Center of Major Machine Manufacturing in Liaoning (Grant No. DUT2017031), Foundation of Collaborative Innovation Center of High-end Control Valve Industry Technology (Grant No. 2018WZ003)

\section{Authors' contributions}

$\mathrm{JL}$ was in charge of the whole trial and wrote the manuscript; $\mathrm{ZH}$ revised the manuscript; 
DD provided some guides to the experiments; XT, QF and YJ undertook some experiments; YZ and YM give some advice to the manuscript. All authors read and approved the final manuscript.

\section{Acknowledgements}

The authors would like to acknowledge the financial support from the Shenyang Blower Works Group Corporation and Wuzhong Instrument Co., Ltd.

\section{References}

[1] JOHN C. LIPPOLD, DAMIAN J. KOTECKI. Welding Metallurgy and weldability of Stainless Steels [M]. Hoboken: John Wiley \& Sons, Inc., 2005: 203-216.

[2] OZLATI A, MOVAHEDI M. Effect of welding heat-input on tensile strength and fracture location in upset resistance weld of martensitic stainless steel to duplex stainless steel rods [J]. Journal of Manufacturing Processes, 2018, 35: 517-525.

[3] EFENDI M, SISKA P, MOCH. S A, et al. Mechanical properties optimization of the modified 410 martensitic stainless steel by heat treatment process [J]. Materials Today: Proceedings, 2018, 5: 14918-14922.

[4] MA X P, WANG L J, QIN B, et al. Effect of N on microstructure and mechanical properties of $16 \mathrm{Cr} 5 \mathrm{Ni} 1 \mathrm{Mo}$ martensitic stainless steel [J]. Materials \& Design, 2012, 34: 74-81.

[5] SAEIDI K, ZAPATA D L, LOFAJ F, et al. Ultra-high strength martensitic 420 stainless steel with high ductility [J]. Additive Manufacturing, 2019, 29: 100803.

[6] WANG Z, LI H, SHEN Q, et al. Nano-precipitates evolution and their effects on mechanical properties of 174 precipitation-hardening stainless steel [J]. Acta Materialia, 2018, 156: 158-171.

[7] NAKASHIMA K, FUTAMURA Y, TSUCHIYAMA T, et al. Interaction between Dislocation and Copper Particles in Fe-Cu Alloys [J]. ISIJ International, 2002, 42(12): 1541-1545.

[8] LEEM D S, LEE Y D, JUN J H, et al. Amount of retained austenite at room temperature after reverse transformation of martensite to austenite in an Fe-13\% Cr-7\% Ni-3\%Si martensitic stainless steel [J]. Scripta Materialia, 2001, 45: 767-772.

[9] KATAYAMA S, KAWAHITO Y, MIZUTANI M. Elucidation of laser welding phenomena and factors affecting weld penetration and welding defects [J]. Physics Procedia, 2010, 5: 9-17.

[10] BAHRAMI B M, NAFFAKH M H. Pulsed Nd:YAG laser welding of 17-4 PH stainless steel: Microstructure, mechanical properties, and weldability investigation [J]. Optics \& Laser Technology, 2019, 119: 105651.

[11] FAN Y H, ZHANG B, YI H L, et al. The role of reversed austenite in hydrogen embrittlement fracture of S41500 martensitic stainless steel [J]. Acta Materialia, 2017, 139: 188-195. 
[12] FANG J X. Evolution and control of stress during laser cladding forming of martensitic stainless steel [D]. Harbin: Harbin Institute of Technology, 2016.

[13] LU S Y, YAO K F, CHEN Y B, et al. The effect of tempering temperature on the microstructure and electrochemical properties of a 13 wt.\% Cr-type martensitic stainless steel [J]. Electrochimica Acta, 2015, 165: 45-55.

[14] BHAMBROO R, ROYCHOWDHURY S, KAIN V, et al. Effect of reverted austenite on mechanical properties of precipitation hardenable 17-4 stainless steel [J]. Materials Science and Engineering: A, 2013, 568: 127-133.

[15] SONG Y, LIX, RONG L, et al. The influence of tempering temperature on the reversed austenite formation and tensile properties in $\mathrm{Fe}-13 \% \mathrm{Cr}-4 \% \mathrm{Ni}-\mathrm{Mo}$ low carbon martensite stainless steels [J]. Materials Science and Engineering: A, 2011, 528(12): 4075-4079.

[16] ZHOU Q Q, ZHAI Y C. Aging process optimization for a high strength and toughness of FV520B martensitic steel [J]. Acta Metallurgica Sinica, 2009, 45(10): 1249-1254.

[17] COUTURIER L, DE GEUSER F, DESCOINS M, et al. Evolution of the microstructure of a 15-5PH martensitic stainless steel during precipitation hardening heat treatment [J]. Materials \& Design, 2016, 107: 416-425.

[18] CAO H W. Development of a nickel saving 7Ni steel for LNG projects and investigation on mechanisms of strengthening and toughening [D]. Hefei: University of Science and Technology of China, 2018.

[19] ZHOU T, FALESKOG J, BABU R P, et al. Exploring the relationship between the microstructure and strength of fresh and tempered martensite in a maraging stainless steel $\mathrm{Fe}-15 \mathrm{Cr}-5 \mathrm{Ni}$ [J]. Materials Science and Engineering: A, 2019, 745: 420-428.

[20] AN J, MENG F, LV X, et al. Improvement of mechanical properties of stainless maraging steel laser weldments by post-weld ageing treatments [J]. Materials \& Design, 2012, 40: 276-284.

\section{Tables}

Table 1 Chemical composition (wt. \%) of FV520B

\begin{tabular}{|lllllllllllll|}
\hline Element & $\mathrm{C}$ & $\mathrm{Si}$ & $\mathrm{Mn}$ & $\mathrm{P}$ & $\mathrm{S}$ & $\mathrm{Cr}$ & $\mathrm{Mo}$ & $\mathrm{Ni}$ & $\mathrm{Cu}$ & $\mathrm{V}$ & $\mathrm{Ti}$ & $\mathrm{Fe}$ \\
\hline Content & 0.05 & 0.36 & 0.52 & 0.027 & 0.027 & 13.72 & 1.44 & 5.65 & 1.71 & 0.05 & 0.01 & Bal. \\
\hline
\end{tabular}

Table 2 Composition at different positions (wt. \%) 


\begin{tabular}{|lllll|}
\hline Position & \multicolumn{2}{l}{ Element } & & \\
\cline { 2 - 5 } & $\mathrm{Cr}$ & $\mathrm{Ni}$ & $\mathrm{Cu}$ & $\mathrm{Fe}$ \\
\hline 1 & 13.42 & 5.30 & 6.75 & Bal. \\
\hline 2 & 13.23 & 8.01 & 3.94 & Bal. \\
\hline 3 & 12.33 & 9.26 & 5.93 & Bal. \\
\hline 4 & 14.25 & 5.26 & 2.77 & Bal. \\
\hline
\end{tabular}

Table 3 Heat treatment parameters of welds

\begin{tabular}{|c|c|c|c|c|c|}
\hline $\begin{array}{l}\text { Specimen } \\
\text { number }\end{array}$ & $\begin{array}{l}\text { Aging } \\
\text { temperature }\end{array}$ & $\begin{array}{l}\text { Holding } \\
\text { time }\end{array}$ & $\begin{array}{l}\text { Specimen } \\
\text { number }\end{array}$ & $\begin{array}{l}\text { Aging } \\
\text { temperature }\end{array}$ & $\begin{array}{l}\text { Holding } \\
\text { time }\end{array}$ \\
\hline 1 & \multirow[t]{4}{*}{$300^{\circ} \mathrm{C}$} & $9 \mathrm{~min}$ & 13 & \multirow[t]{4}{*}{$600^{\circ} \mathrm{C}$} & $9 \mathrm{~min}$ \\
\hline 2 & & $1 \mathrm{~h}$ & 14 & & $1 \mathrm{~h}$ \\
\hline 3 & & $2 \mathrm{~h}$ & 15 & & $2 \mathrm{~h}$ \\
\hline 4 & & $12 \mathrm{~h}$ & 16 & & $12 \mathrm{~h}$ \\
\hline 5 & \multirow[t]{4}{*}{$400^{\circ} \mathrm{C}$} & $9 \mathrm{~min}$ & 17 & \multirow[t]{4}{*}{$650^{\circ} \mathrm{C}$} & $9 \mathrm{~min}$ \\
\hline 6 & & $1 \mathrm{~h}$ & 18 & & $1 \mathrm{~h}$ \\
\hline 7 & & $2 \mathrm{~h}$ & 19 & & $2 \mathrm{~h}$ \\
\hline 8 & & $12 \mathrm{~h}$ & 20 & & $12 \mathrm{~h}$ \\
\hline 9 & \multirow[t]{4}{*}{$550^{\circ} \mathrm{C}$} & $9 \min$ & 21 & \multirow[t]{3}{*}{$900^{\circ} \mathrm{C}$} & $9 \mathrm{~min}$ \\
\hline 10 & & $1 \mathrm{~h}$ & 22 & & $1 \mathrm{~h}$ \\
\hline 11 & & $2 \mathrm{~h}$ & 23 & & $2 \mathrm{~h}$ \\
\hline 12 & & $12 \mathrm{~h}$ & & & \\
\hline
\end{tabular}

Figures 


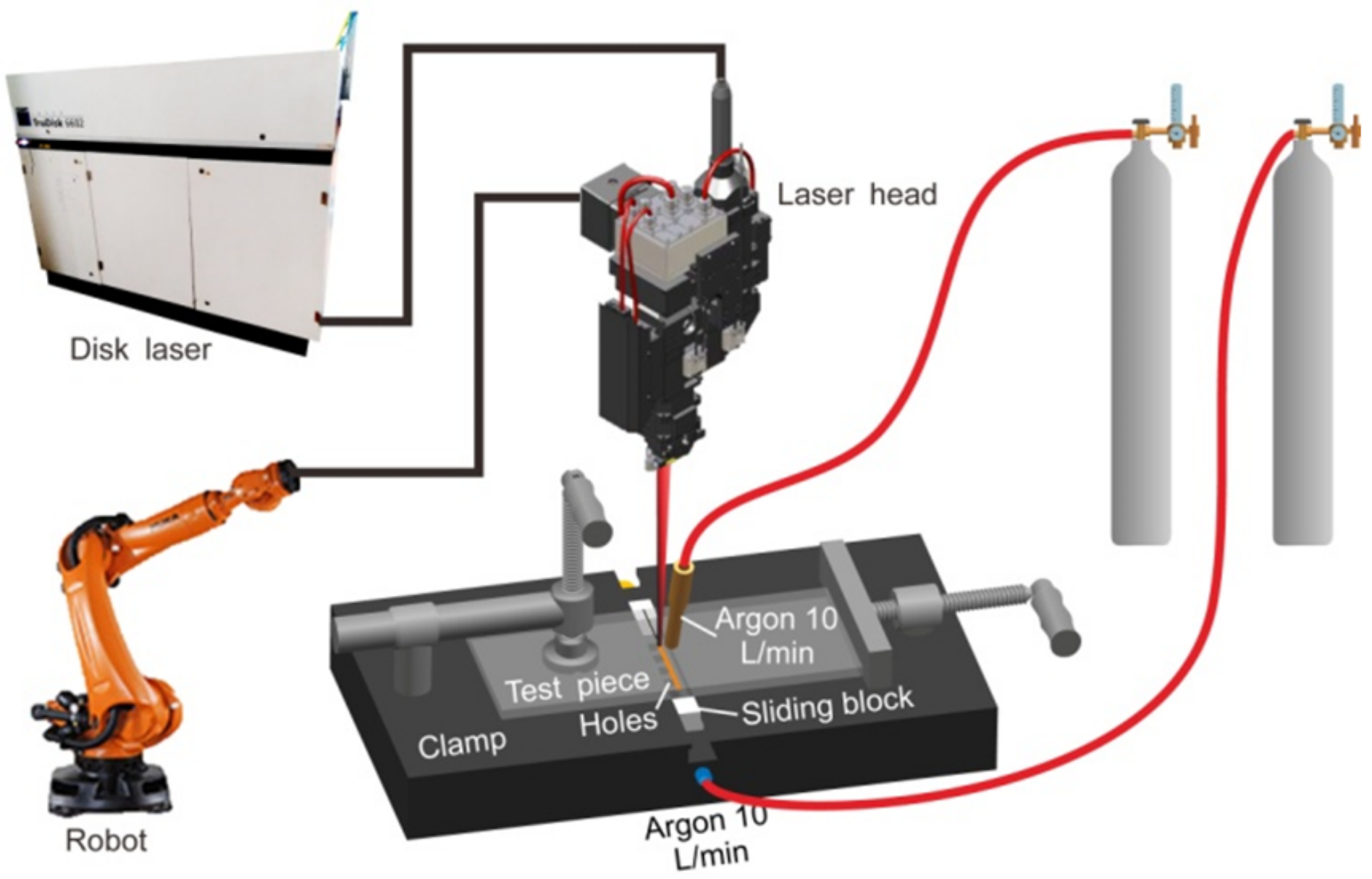

Figure 1

Experimental equipment of laser welding 

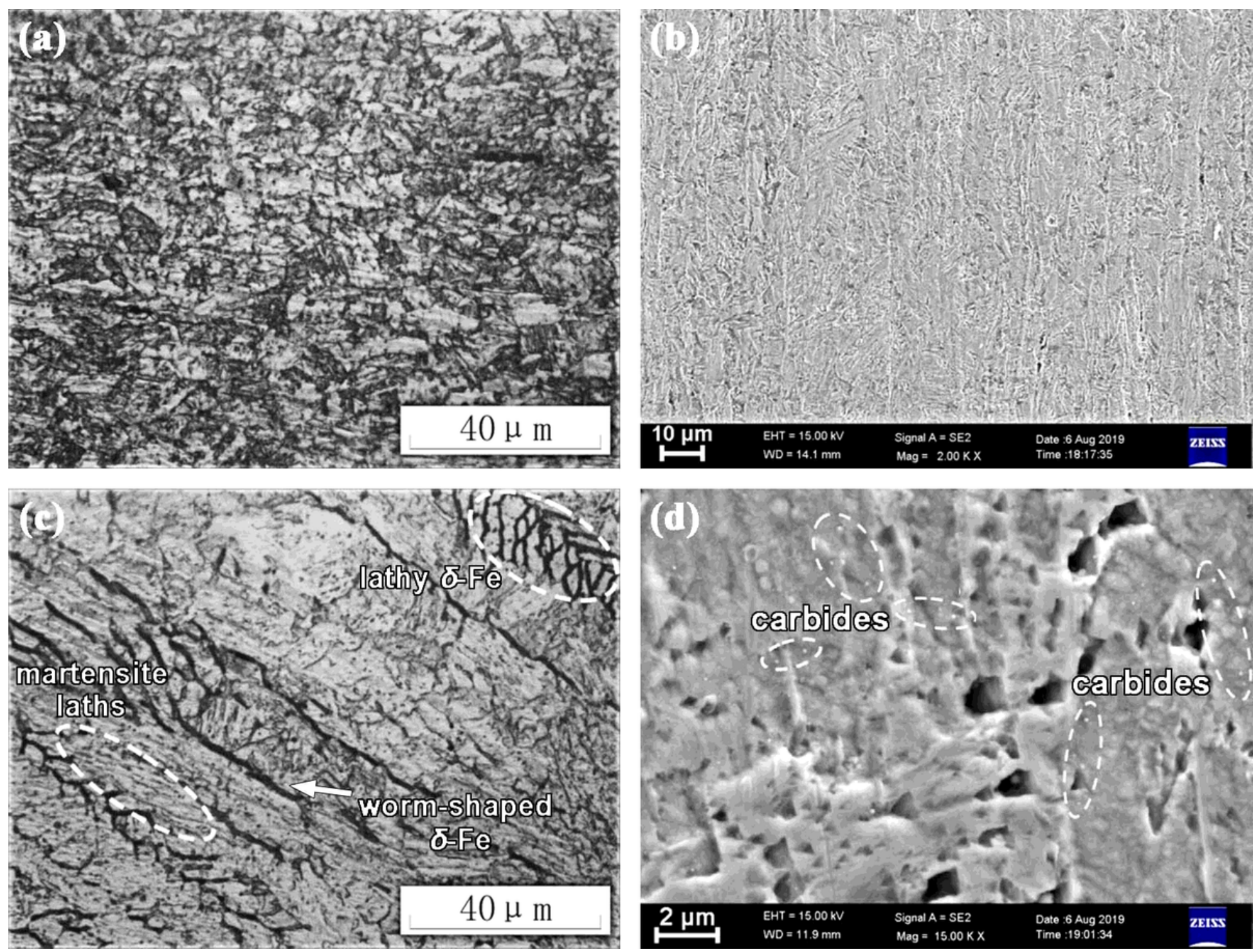

\section{Figure 2}

Metallographic and SEM images of microstructures in BM (a, b) and FZ (c, d) 


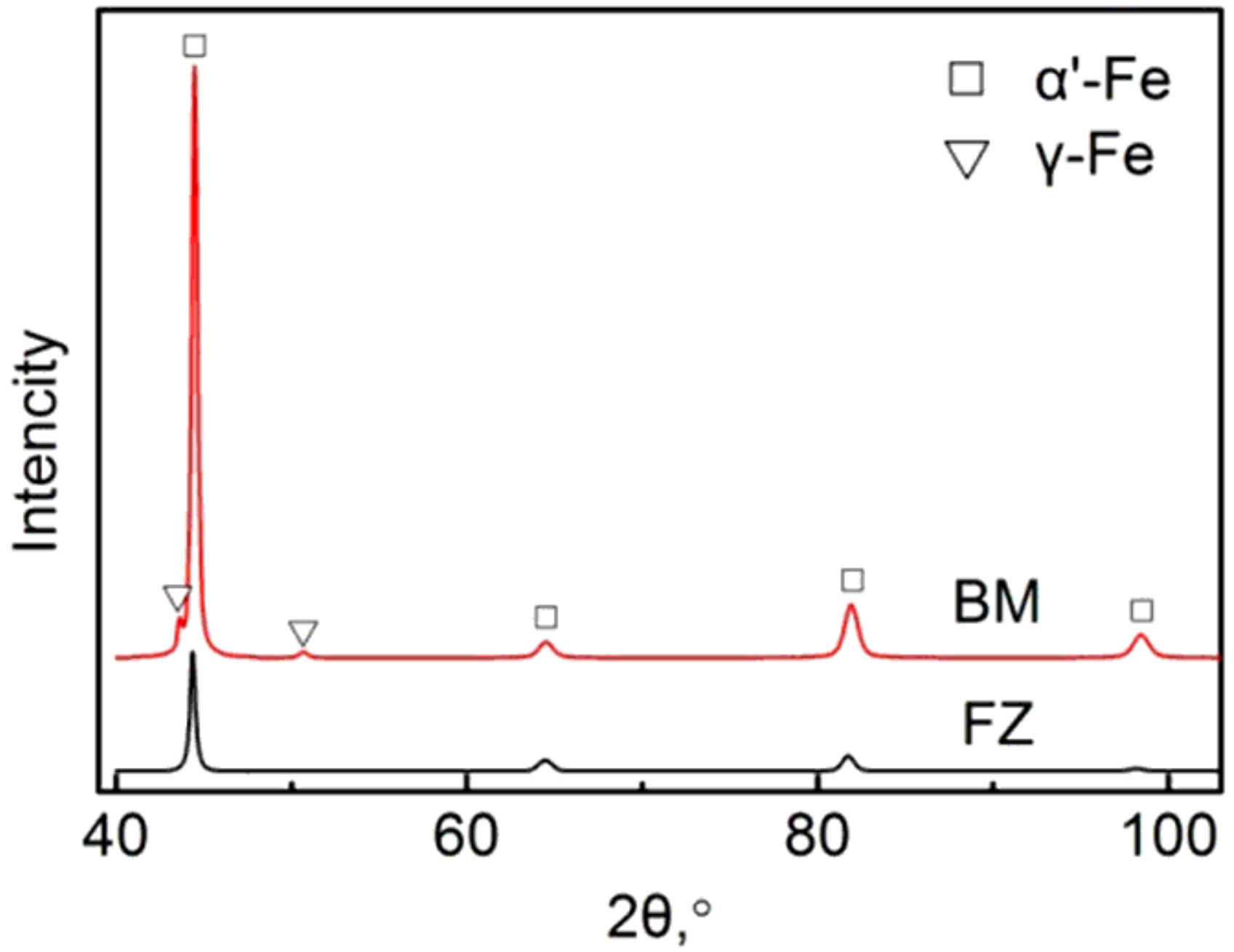

Figure 3

X-ray diffraction spectrum of BM and FZ 


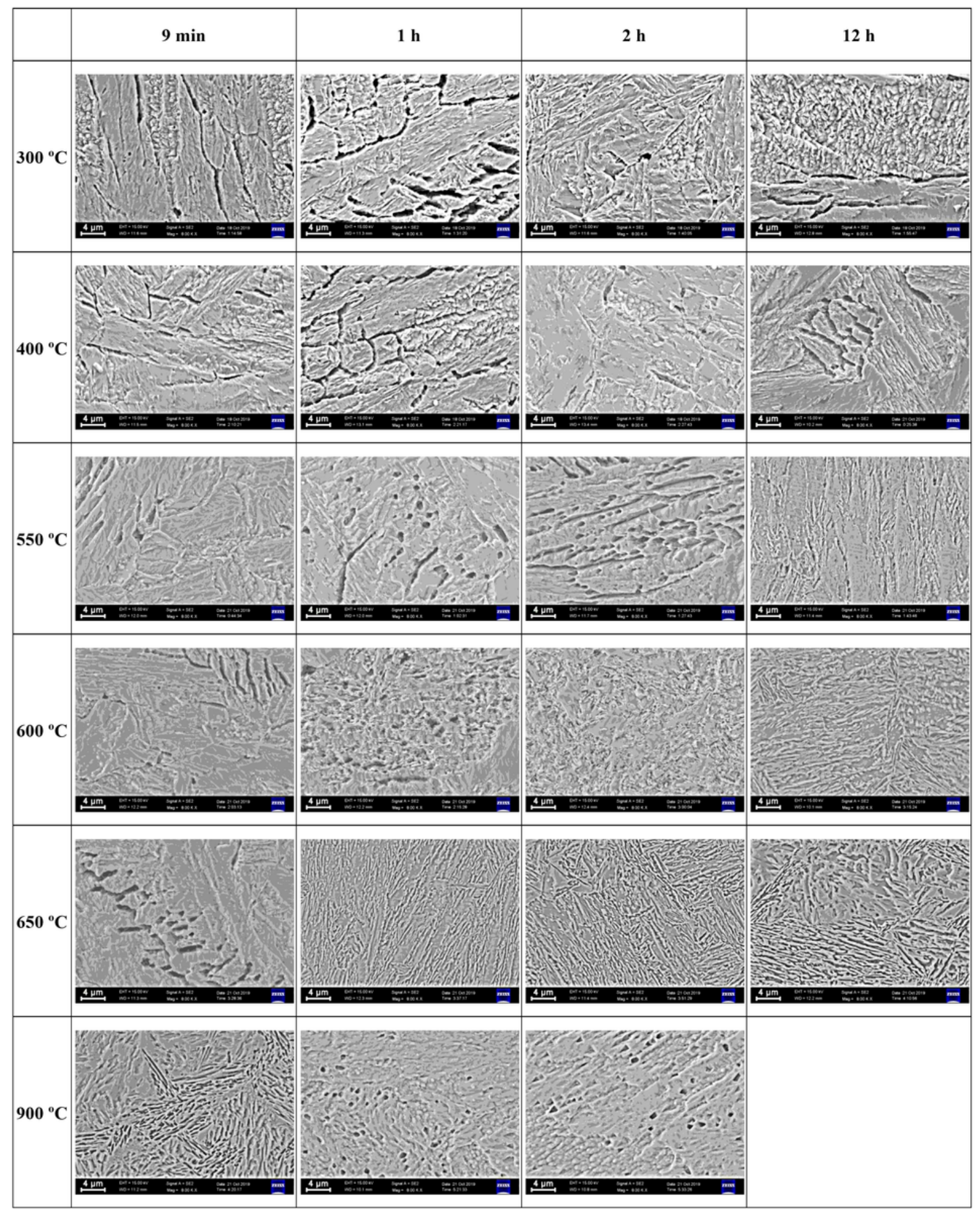

Figure 4

Microscopic morphologies of FZ under different heat treatment processes $(\times 8000)$ 

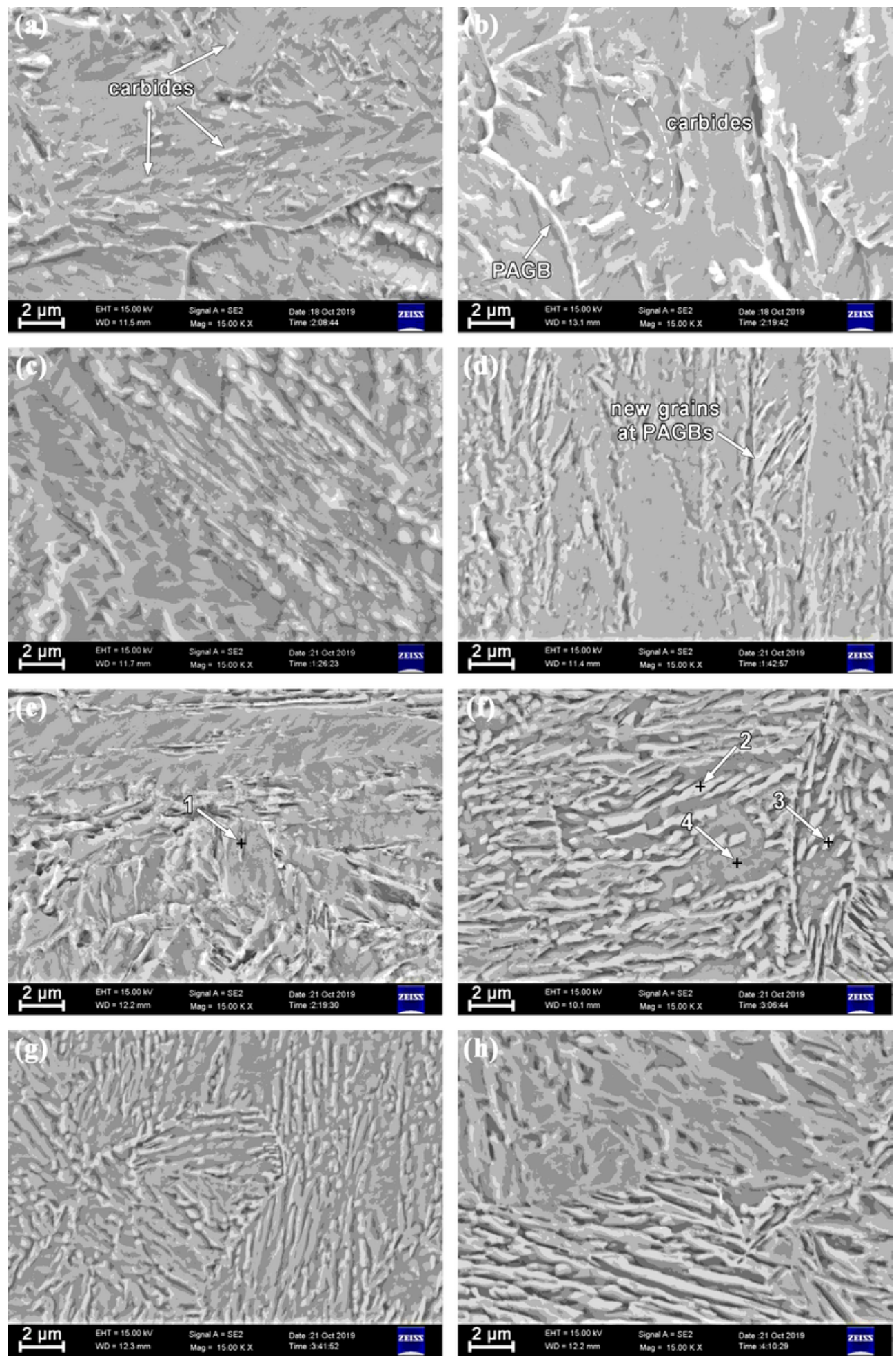

\section{Figure 5}

Microstructure of FZ under different heat treatment parameters ( $\times 15000)$ : (a) $400{ }^{\circ} \mathrm{C}, 9 \mathrm{~min}$; (b) $400{ }^{\circ} \mathrm{C}, 1 \mathrm{~h}$; (c) $550^{\circ} \mathrm{C}, 2 \mathrm{~h}$; (d) $550{ }^{\circ} \mathrm{C}, 12 \mathrm{~h}$; (e) $600{ }^{\circ} \mathrm{C}, 1 \mathrm{~h}$; (f) $600{ }^{\circ} \mathrm{C}, 12 \mathrm{~h}$; (g) $650{ }^{\circ} \mathrm{C}, 1 \mathrm{~h}$; (h) $650{ }^{\circ} \mathrm{C}, 12 \mathrm{~h}$ 

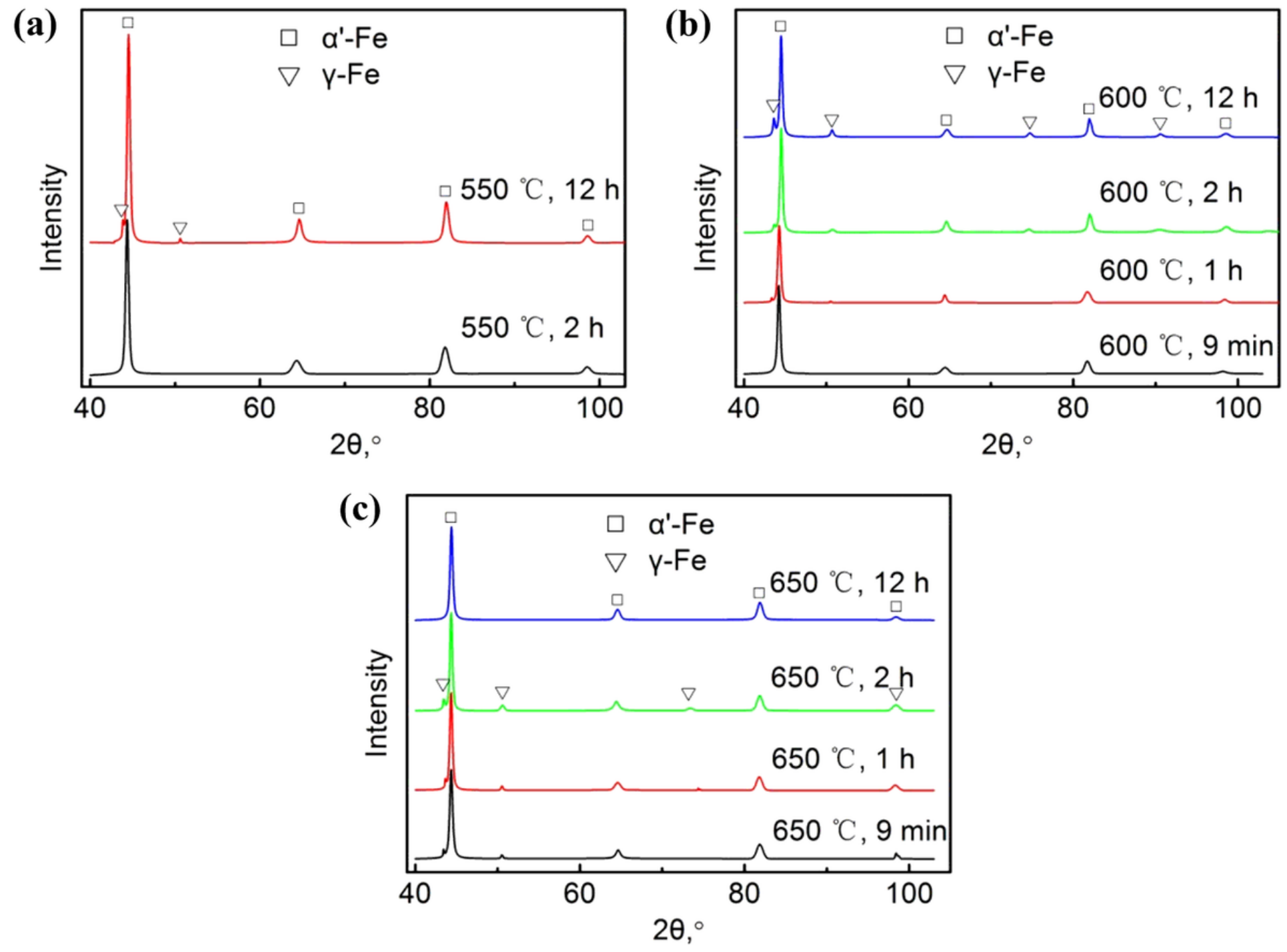

Figure 6

X-ray diffraction spectrum of FZ under different heat treatment conditions 


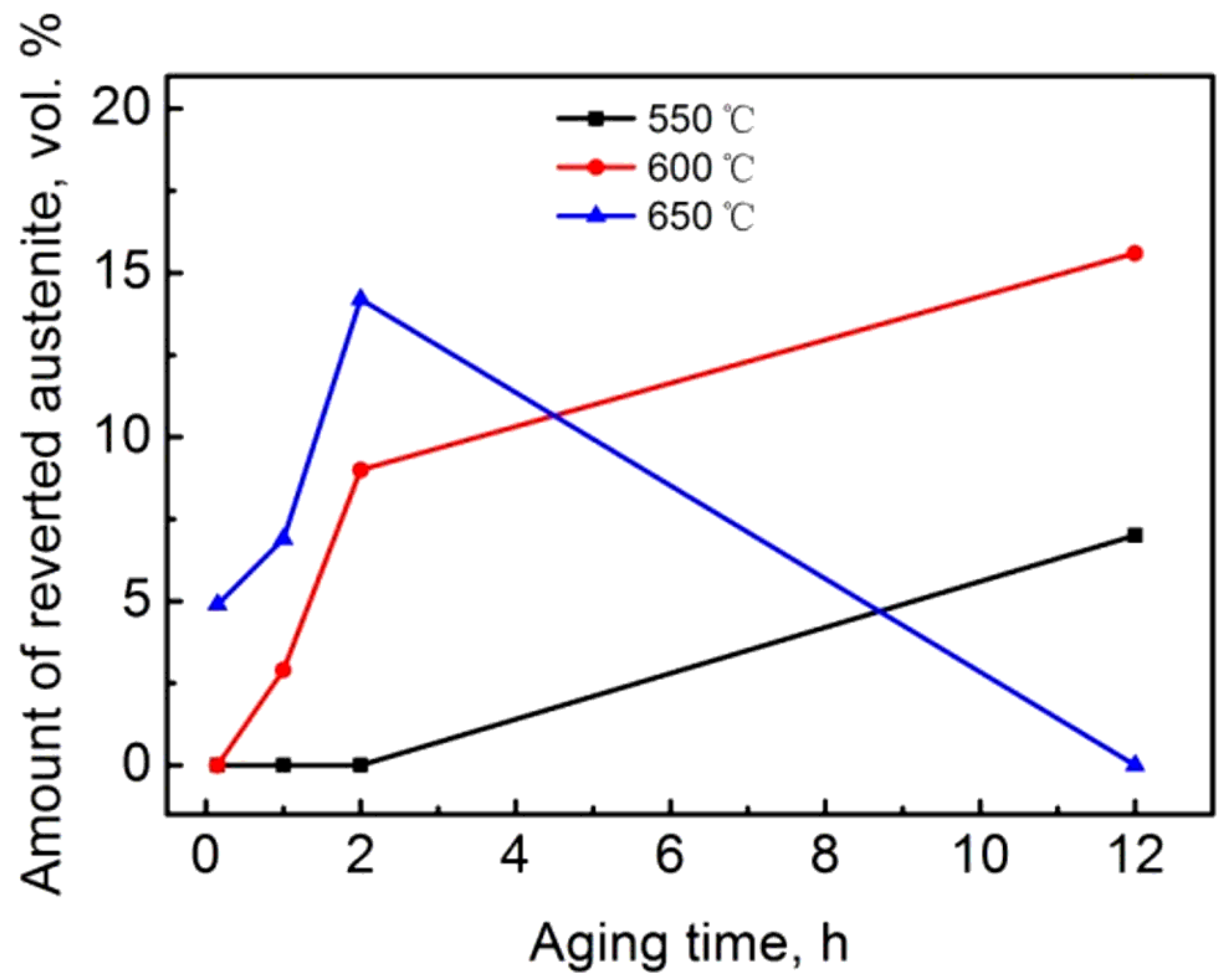

Figure 7

Relation between the content of reversed austenite and aging time at different aging temperatures 
(a)

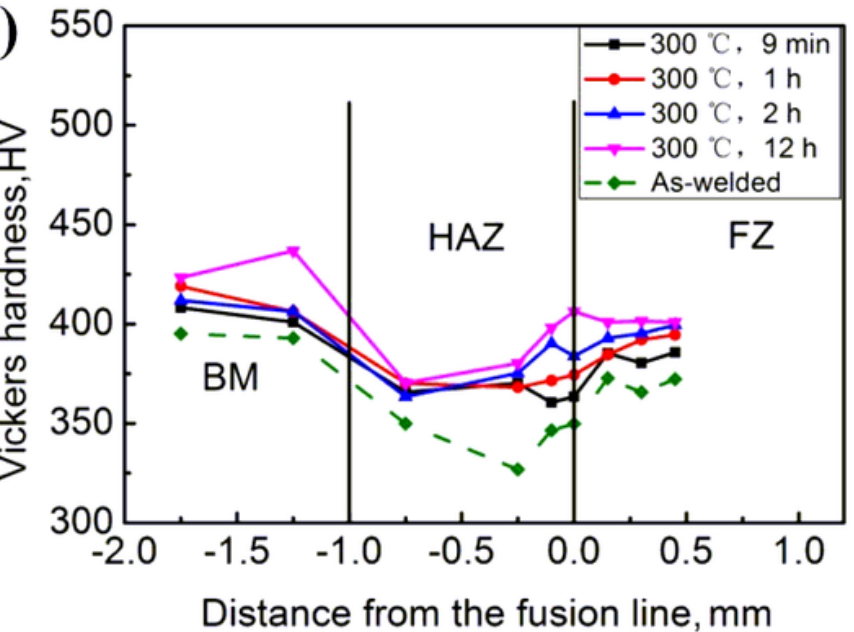

(c)

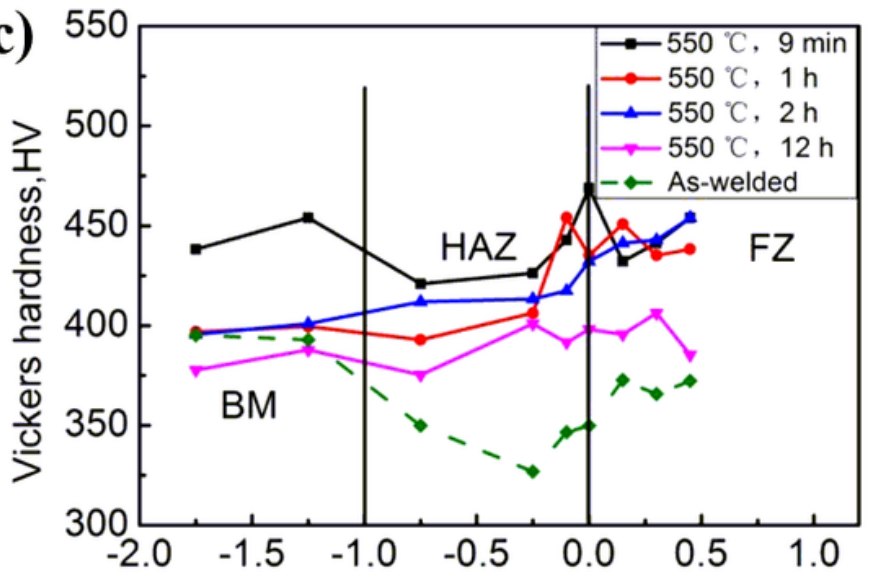

Distance from the fusion line, $\mathrm{mm}$

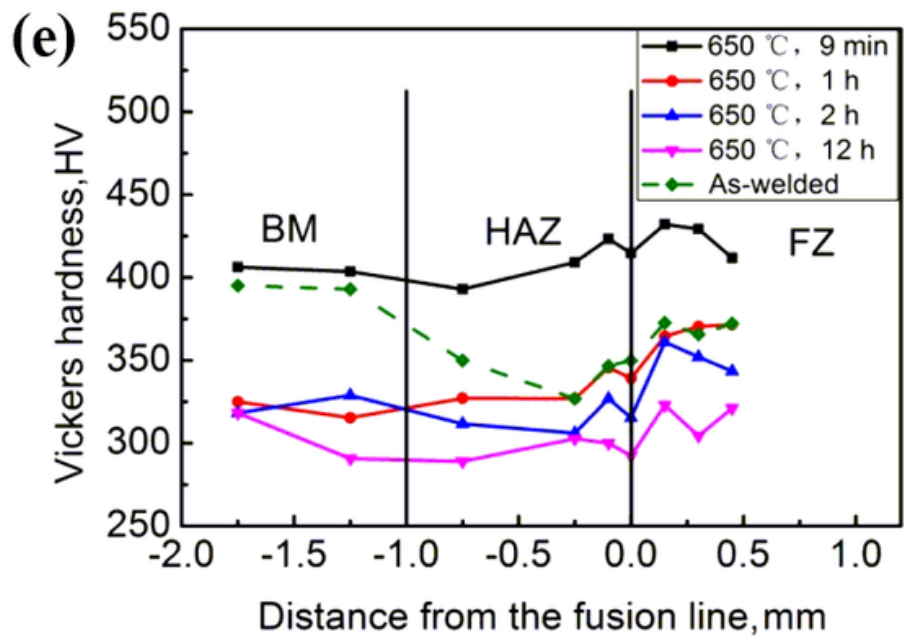

(b)

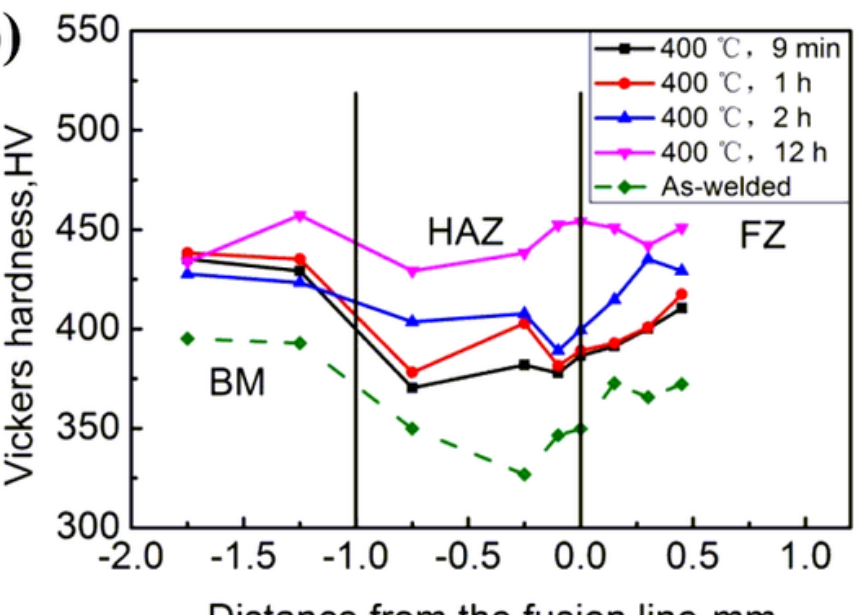

Distance from the fusion line, $\mathrm{mm}$

(d)

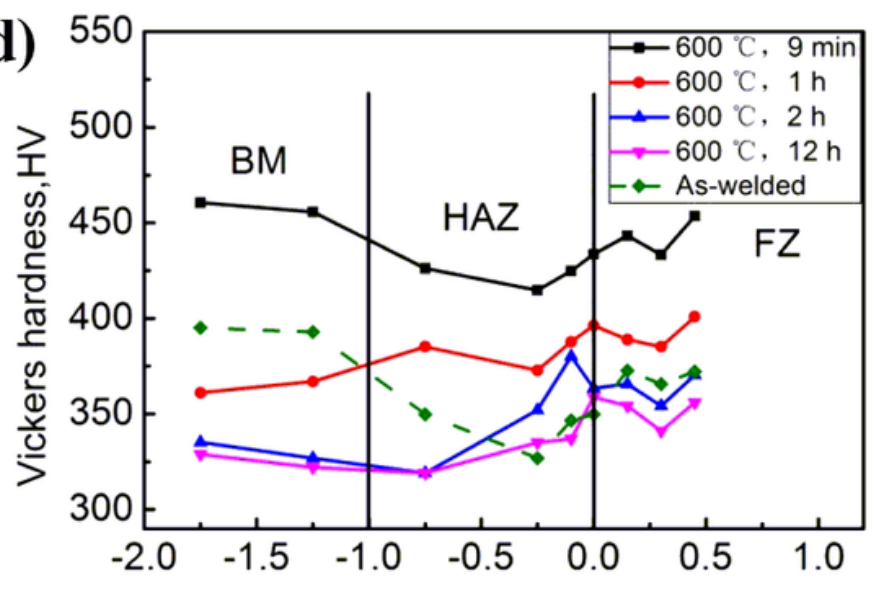

Distance from the fusion line, $\mathrm{mm}$

(f)

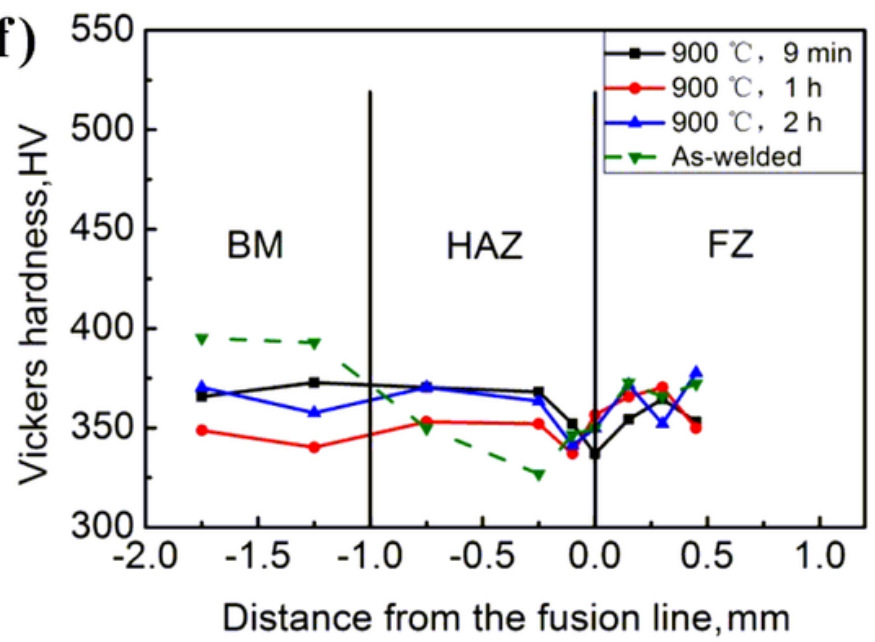

Figure 8

Vickers hardness profiles on the weld cross sections under different heat treatment conditions 


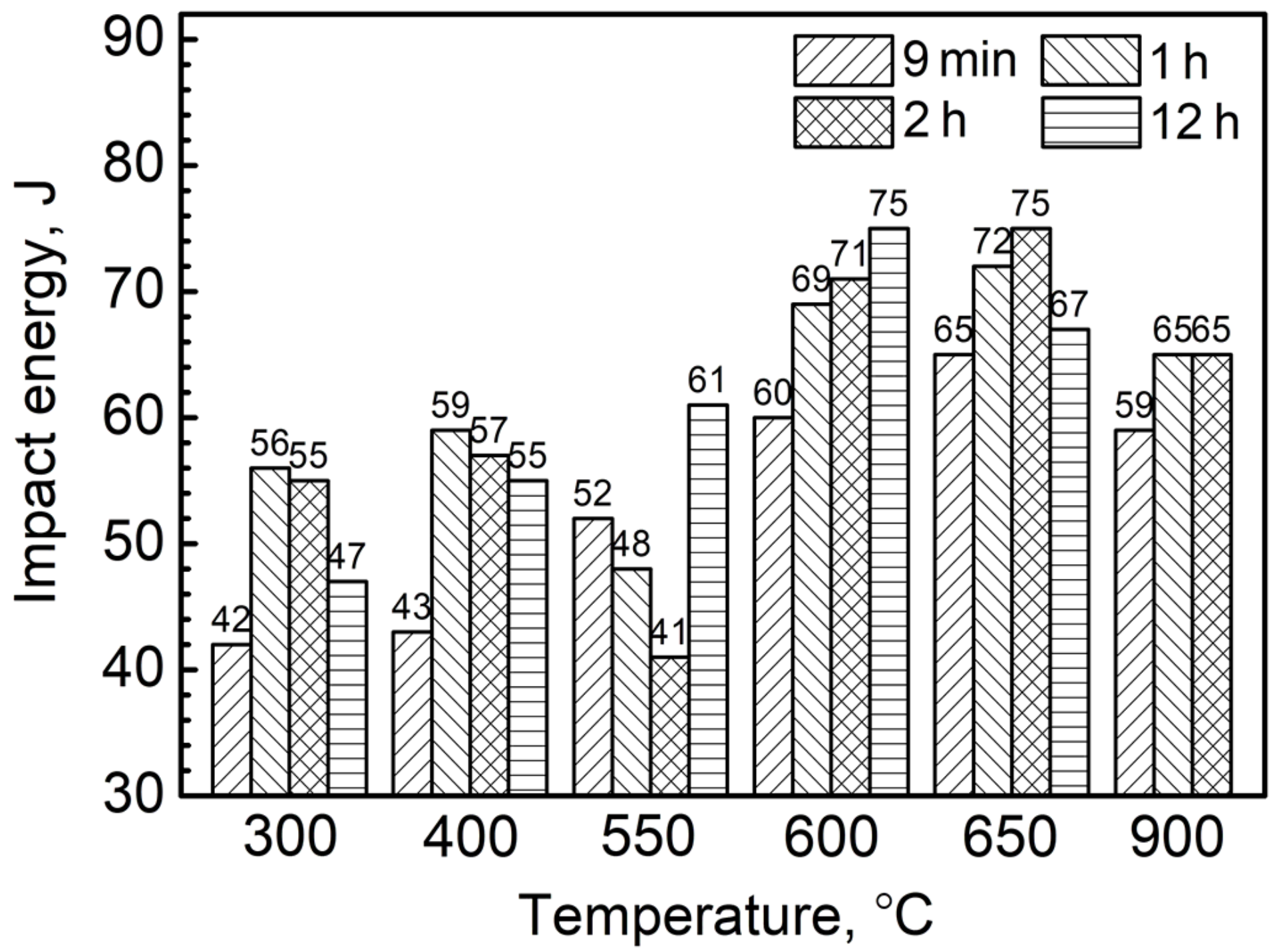

Figure 9

Absorbed impact energy of welds under different heat treatment conditions 

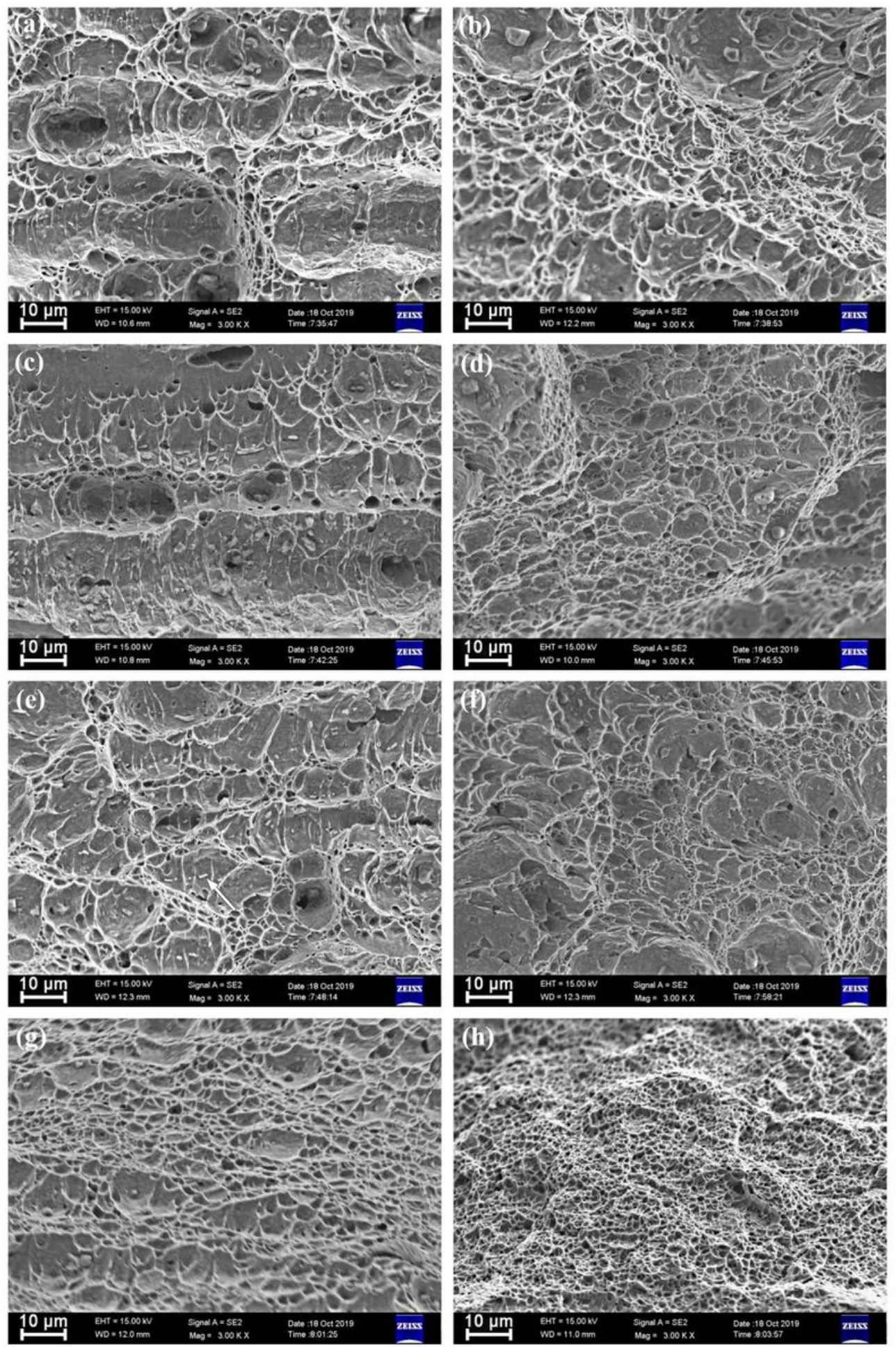

Figure 10

Fracture morphologies of the specimens under different holding time at $550^{\circ} \mathrm{C}$ and $650^{\circ} \mathrm{C}$ : (a) $550^{\circ} \mathrm{C}, 9$ min; (b) $650^{\circ} \mathrm{C}, 9 \mathrm{~min}$; (c) $550^{\circ} \mathrm{C}, 1 \mathrm{~h}$; (d) $650^{\circ} \mathrm{C}, 1 \mathrm{~h}$; (e) $550^{\circ} \mathrm{C}, 2 \mathrm{~h}$; (f) $650^{\circ} \mathrm{C}, 2 \mathrm{~h}$; (g) $550^{\circ} \mathrm{C}, 12 \mathrm{~h}$; (h) 650 ${ }^{\circ} \mathrm{C}, 12 \mathrm{~h}$ 


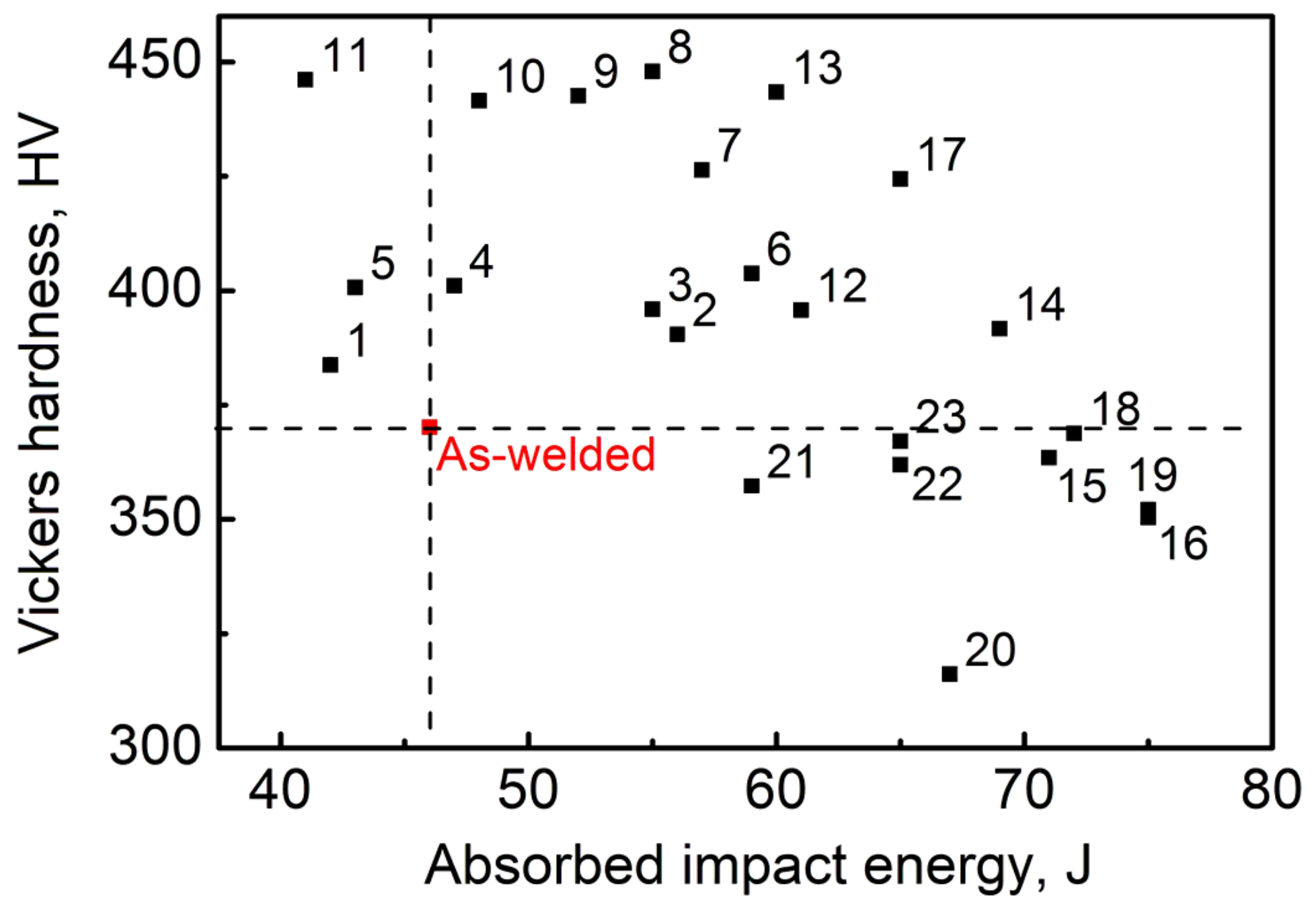

Figure 11

Scatter diagram of Vickers hardness vs. impact energy of FZ 